\title{
Marketing and price spread analysis of moringa in Tamil Nadu, India
}

\begin{abstract}
The export of Moringa leaves is a big business in Tamil Nadu, Andhra Pradesh, Karnataka and Odisha. The major countries which import Moringa leaves are China, U.S.A., Germany, Canada, South Korea and European countries. Though the existing arrangements for marketing of farm produce are appreciable, there could be some gap in Institutional linkages and hence an attempt has been made to assess the existing marketing practices prevalent in respect of Moringa farmers of Southern Tamil Nadu. The study has found out that the traders of Moringa are accounted to be around 255 in numbers whom are spread in 17 states of India. Among the 17 states, Tamil Nadu is the forerunner with large number of traders whom are exclusively dealing the different produce of Moringa. They are coming under the category of Manufacturer cum Exporter or the Wholesalers and Distributors of Moringa produce. Tamil Nadu is alone blessed with 149 traders whom are accounted for 58 per cent to the total number of traders available in the country revealed indirectly that the Tamil Nadu is the potential pocket for resource mobilization for trading in respect of Moringa followed by Gujarat is accounted for 14 per cent. Tamil Nadu is blessed with 4 important trading centers for Moringa produce. They are Udangudi of Thoothukkudi District; Aundipatti of Theni District; Aravakkurichi of Karur District and Oddanchatram of Dindigul District. In respect of Fresh Moringa (Drumstick), there were three marketing channels through which the fresh Moringa pods were distributed to the ultimate consumers. In respect of value added products of Moringa, there were three channels involved in distribution of the produce to the ultimate consumers. Among the three channels, two are domestically operating pathways and the one is devoted for export of Moringa produce. Among the three channels of Fresh Moringa pods, the Channel - I was found to be efficient with respect to addition of higher share to the producers. The supply and value chain in respect of Moringa are not well defined and regulated and are distributed to the needy through some middlemen. Being the demand oriented and high revenue earner, the regulated supply and value chain becomes important.
\end{abstract}

Keywords: marketing of moringa, value addition of moringa, marketing channels, price spread, marketing efficiency
Volume 2 Issue 4 - 2018

\author{
NVenkatesan,' C Sekhar, ${ }^{2}$ M Murugananthi, ${ }^{3}$ \\ A Vidhyavathi ${ }^{2}$ \\ 'Research Scholar, Department of Social Sciences, Agricultural \\ College and Research Institute, India \\ 2Department of Agricultural Economics, Tamil Nadu Agricultural \\ University, India \\ ${ }^{3}$ Department of Agricultural and Rural Management, TNAU, \\ India
}

Correspondence: $C$ Sekhar and A Vidhyavathi, Department of Agricultural Economics, Tamil Nadu Agricultural University, Coimbatore-64I 003, India, Email saekarck@gmail.com

Received: May 28, 2018 | Published: August 31, 2018

\section{Introduction}

Moringa leaves have been reported to be a rich source of $\beta$-carotene, protein, vitamin $C$, calcium and potassium and act as a good source of natural antioxidants; and thus, enhance the shelflife of fat containing foods due to the presence of various types of antioxidant compounds such as ascorbic acid, flavonoids, phenolic and carotenoids. In the Philippines, it is known as 'mother's best friend' because of its utilization to increase woman's milk production and is sometimes prescribed for anemia. ${ }^{1,2}$ Interestingly, 80 per cent of the production of Moringa leaves in India, fetching higher share of foreign exchange to the country. Growing at a rate of 26-30 per cent annually, the export of Moringa leaves is a big business in Tamil Nadu, Andhra Pradesh, Karnataka and Odisha. The major countries which import Moringa leaves are China, the US, Germany, Canada, South Korea and European countries. India exported Moringa leaves worth Rs 14.6crores in 2015, compared to Rs 11.61 crores in 2014. The export of these leaves worth Rs 2.50crores in January and February of 2016. The latest trend in the Moringa market is the shift towards organic leaves and usage of solar driers (APEDA).

\section{Production of moringa}

India is the prime producer of Moringa (Drumstick) with an annual production of 2.2 million tonnes of tender fruits from an area of 43,600 ha leading to the productivity of around 50 tonnes per ha. Among the different states, Andhra Pradesh leads in both area and production $(15,665 \mathrm{ha})$ followed by Tamil Nadu (13042ha) and Karnataka (10,280ha). In other states, it occupies an area of $4,613 \mathrm{ha}$. Tamil Nadu is the pioneering state as it has varied genotypes from diversified geographical areas, as well as introductions from Sri Lanka. In Tamil Nadu, Moringa was cultivated as sole crop in homesteads, around cattle sheds, on farm boundaries, and as isolated plants in fences and as groups of trees on village waste lands. In the early 1990s, in Southern Tamil Nadu, people have started growing perennial Moringa types in Moolanur block of Dharapuram taluk, Moringa is established as an intercrop on field in a large scale and their allies were cropped with vegetables and Sorghum formed a Moringa based intercropping system. This Moringa based cropping system was evolved as a protection to alley crops from drying winds during summer and Moringa has also provided some additional income. With the migration of people from South to North India, and elsewhere in the world, the Moringa cultivation and the demand for Moringa has picked up.

Farmers found that growing Moringa crops during summer season was remunerative. Thus, Moringa gained a foothold as a summer vegetable. Its unique flavor and aroma became very popular. For South Indian any meal without Moringa and pulses is considered incomplete. The demand for the Moringa pods also has increased due to the increased urban settlements and migration of people to urban 
colonies. Based on the significance of Moringa in the human diet, this study might be more viable with the specific objectives of assessing the production and marketing practices of Moringa prevalent in the Western and Southern Districts of Tamil Nadu. Tamil Nadu is one of the largest producers of Moringa with an annual production of 6.71lakh tonnes of tender fruits from an area of 13042ha. Among the Districts, Theni leads in both area and production (3424ha) followed by Dindigul (2645ha), Karur (2070ha), Thoothukkudi (1465ha),
Tiruppur (1191ha), Ariyalur (813ha) and Madurai (536ha). These details are analyzed and presented in Table 1 . Table 1 revealed that the area under Moringa is skewed to certain districts because of the good soil conditions and becomes good revenue earner among the rural households and hence Moringa cultivation in these districts becomes popular one. In Tiruppur District, the Moolanur Block had the highest area under Moringa next to Sathankulam of Thoothukkudi District. Sathankulam had become the hub of Moringa cultivation.

Table I Area under moringa in different districts of Tamil Nadu

\begin{tabular}{|c|c|c|c|c|}
\hline SI. No. & $\begin{array}{l}\text { Name of the } \\
\text { District }\end{array}$ & $\begin{array}{l}\text { Area under Moringa } \\
\text { (Ha) }\end{array}$ & $\begin{array}{l}\text { Percentage to total area under moringa in } \\
\text { Tamil Nadu }\end{array}$ & $\begin{array}{l}\text { Average Productivity / } \\
\text { Position }\end{array}$ \\
\hline 1 & Theni & 3424 & 26.25 & First \\
\hline 2 & Dindigul & 2645 & 20.28 & Second \\
\hline 3 & Karur & 2070 & 15.87 & Third \\
\hline 4 & Thoothukkudi & 1465 & 11.23 & Fourth \\
\hline 5 & Tiruppur & 1191 & 9.13 & Fifth \\
\hline 6 & Ariyalur & 813 & 6.23 & Sixth \\
\hline 7 & Madurai & 536 & 4.11 & Seventh \\
\hline \multirow[t]{2}{*}{8} & Other Districts & 898 & 6.89 & \\
\hline & Total Area in Ha & 13042 & 100 & 51.45 \\
\hline
\end{tabular}

Source: Season and crop report of Tamil Nadu (2015-16)

\section{Problem focus}

Though the existing arrangements for marketing of farm produce are appreciable, there could be some gap in Institutional linkages, empowering farmers' organizations and their role in marketing of farm produce like Moringa. Whether these arrangements are fulfilled by the Government for facilitating marketing and export of Moringa through some institutional arrangement or not is unavailable to the researcher. And hence an attempt has been made to assess the existing marketing practices prevalent in respect of farmers of southern Tamil Nadu. Though India had higher market access among the Global partners with regard to the Moringa, still some consignments in fruits are rejected by certain countries for want of sanitary and phytosanitary issues and the specification of the importing country is unmet and hence rejection is visible. In this respect, the role of APEDA is giving an orientation to the exporters through appropriate package of training and the strict adherence of quality norms is a must. In this respect, an attempt has also been made to document the status of marketing and trading of Moringa to different countries and the issues connected with the export of Moringa to enhance the trade in horticultural produce. On finding the solutions to the above issues and adoption of the strategies on time that emanated from the study, the horticultural development could be on the dynamic track and the hassle-free marketing and export could be visualized. For that purpose the objectives are framed as to identify the marketing channels and assess the marketing efficiency of these channels.

\section{Objectives}

1. To assess the existing marketing practices prevalent in respect of farmers of southern Tamil Nadu.

2. To identify the Marketing Channels Prevalent in the process of Distribution of various Produce of Moringa and
3. To assess the Marketing efficiency of the Marketing Channels Practiced for Distribution.

\section{Methodology}

Among the Vegetables, Moringa is the one which is used very commonly by the people of South India for its flavor and delicious taste in Sambar and Curry preparation. Besides, it is also a source of several medicinal properties and hence the crop commands significance in cultivation. Every household will be maintaining one or two Moringa tree in their homestead considering its importance and is grown almost in all the districts of Tamil Nadu and South India.

\section{Selection of traders}

To assess the marketing practices followed by the farmers and the traders, a separate questionnaire has been designed as delineated elsewhere and the questionnaire has been tested and made fit for survey. Before entering into the survey, the numbers of traders who are dealing with Moringa marketing were enlisted by conducting inquiries with the officials of Department of Agriculture and the General traders in the villages of Sathankulam Taluk and the Dharapuram Taluks. Besides website sources were also used. From the list 10 traders in each of the taluk whom are dealing with Moringa and the value-added products of Moringa were selected and interviewed for the study. The details of villages in which the traders selected were presented in Table 2. For the study as a whole, the aggregate sampling was one hundred farmers whom are cultivating Moringa in their farms and 20 Traders viz., 10 each from Sathankulam Taluk and Dharapuram Taluks were selected forming a sum of 120 samples. Their marketing practices were documented in the results and discussion section following a percentage analysis. 
Table 2 Details of the traders selected for the study

\begin{tabular}{llll}
\hline Sl. No. & $\begin{array}{l}\text { Name of the Villages in } \\
\text { which Traders Selected in } \\
\text { Sathankulam Taluk }\end{array}$ & $\begin{array}{l}\text { Number of } \\
\text { Samples }\end{array}$ & $\begin{array}{l}\text { Name of the Villages in which Traders } \\
\text { Selected in Dharapuram Taluk }\end{array}$ \\
\hline 1 & Sasthavinallur & 2 & Kumber of \\
Samples & Kilangundal \\
2 & Naduvakkurichi & 2 & Komarapalayam \\
3 & Mudhalur & 2 & Mulayampoondi \\
4 & Arasoor & 2 & Mulanur \\
5 & Thatchamozhi & 2 & Puduppai \\
Total Samples under Moringa & & 10 & Total Samples under Moringa \\
\hline
\end{tabular}

\section{Price spread analysis}

Price Spread in general, is referred to as the difference between the price paid by the Consumer and the Price received by the Producers per unit of the commodity. Price Spread analysis would estimate the share of different market intermediaries in the consumers' rupee and this would often facilitate the understanding of the relative efficiencies otherwise of alternative channels in marketing. Information on prices prevailed and the cost involved in marketing of Moringa at different stages of all identified marketing channels were collected from the farmers and market functionaries. The cost of marketing included cost spent on packing, grading, transport, loading and unloading, storage and other incidental expenses incurred for marketing the farm produce. In this study, the price spread analysis involved computation of marketing cost and the profit margin and their expression as a percentage to the consumer's rupee. Moreover, the farmers' share in the consumer's rupee was also worked out in the estimation of price spread.

To analyze the Prize Spread in the distribution of Moringa produce, the following formula is used.

Where,

$$
P s=(P p / C p) \times 100
$$

Ps $=$ Producer's share in the consumer money expressed in per cent

$\mathrm{Cp}=$ Consumer's Price per unit of Moringa in Rupees

$\mathrm{Pp}=$ Producer's Price per unit of Moringa in Rupees.

Similar approach was used by Sekhar et $a .^{3}$ The price spread analysis involved in computation of different marketing cost and marketing margin at each stage and their expression as a percentage to the consumer's rupee. The various costs incurred in the marketing process were considered for each of the identified channels and separate price spread was worked out. The profit margin for each market functionaries in the different marketing channels was computed by subtracting the price paid and the marketing cost incurred by them from the price received by him on the sale of the commodity. Thus, the marketing costs and marketing margins were distinguished.

\section{Estimation of marketing efficiency}

Marketing Efficiency is the degree of market performance. The movement of Moringa from producers to the ultimate consumers at the lowest possible cost consistent with the provision of service desired by the consumer is termed as efficiency in marketing. Acharya
\& Agarwal ${ }^{4}$ compared relative efficiency of different markets by using the following formula

$$
E=(O / I)
$$

Where,

$\mathrm{E}=$ Marketing Efficiency Expressed in Percentage

$\mathrm{O}=$ Value added Output in the Marketing System

$\mathrm{I}=$ Input used in the Marketing Process

The Lower the value higher would be the efficiency.

\section{Results and discussion}

\section{Markets and marketing practices in moringa produce}

Any production activity should find an appropriate outlet for its distribution through appropriate intermediaries for effective and efficient time bound transfer so that the quality of the produce can be protected and restored to gain consumer advantage and their acceptability. Hence, grading, standardization, meeting the priorities of the consumer either at domestic market or at the international market becomes priority. An experienced trader or the manufacturer or the exporter is well experienced on these issues. On these lines, the markets and marketing practices practiced by the traders and the farmers are described under the following heads.

1. Details of Firms involved in Trading the Produce of Moringa

2. Details of Assembling Centers and Trading Potentials of Moringa

3. Marketing Channels in the Distribution of Moringa Produce

4. Price Spread in Marketing of Moringa Produce

\section{Details of firms involved in trading the produce of moringa}

In India, plenty of traders whom are exclusively dealing with the value added or fresh produce of Moringa in addition to other exportable produce, are available in different states of the country and are enlisted, analyzed and the results are presented in Table 3 . The traders of Moringa are accounted to be around 255 in numbers whom are spread in 17 states of India. Among the 17 states, Tamil Nadu is the forerunner with large number of traders whom are exclusively dealing the different produce of Moringa. They are coming under the category of Manufacturer cum Exporter or the Wholesalers and Distributors of Moringa produce. Table 3 revealed that Tamil Nadu alone is blessed 
with 149 traders whom are accounted for 58 per cent to the total number of traders available in the country revealed indirectly that the Tamil Nadu is the potential pocket for resource mobilization for trading in respect of Moringa followed by Gujarat accounted for 14 per cent. Around 72 per cent of the traders of Moringa produce are available only in these two states. Whereas, the states like Madhya Pradesh, Maharashtra and Karnataka and Rajasthan are on par with each other with their share of around 3 to 4 per cent to the total number of traders. Though the Moringa is spread in different states, the state like Tamil Nadu alone has sufficient data and the data for area under Moringa is not available in different State's data sources and hence the potentials available across the country in terms of Moringa resources could not be documented. Being Tamil Nadu is the forerunner in terms of number of traders dealing with Moringa produce, the district wise existence of traders is analyzed and the results are presented in Table 4. Tamil Nadu is blessed with 149 traders whom are actively involved in promotion of trade of Moringa based products (Table 4) and are spread in 24 districts of Tamil Nadu. Among the 24 districts, Coimbatore District alone had 36 traders whom are accounted for 24 per cent to the total number of traders available in Tamil Nadu followed by Chennai District blessed with 23 traders whom are accounted for 15 per cent to the total. Madurai District had only 15 traders whom are accounted for 10 per cent to the total. Whereas Dindigul, Tiruppur and Erode Districts had almost 8 to 10 traders whom are accounted for only around 7 per cent to the total, it revealed that the Coimbatore, Chennai, Madurai, Dindigul, Erode and Tiruppur are the potential areas where one can access more number of Moringa resources for value addition and export. Similar types of analysis were drawn by Sekhar ${ }^{5}$ for marketing analysis of Curd Chilli.

Table 3 Details of firms involved in manufacturing / trading produce of moringa in India

\begin{tabular}{|c|c|c|c|}
\hline SI. No. & Particulars of States & $\begin{array}{l}\text { Number of } \\
\text { Firms Involved }\end{array}$ & $\begin{array}{l}\text { Percentage to } \\
\text { Total }\end{array}$ \\
\hline 1 & Andhra Pradesh & 4 & 1.57 \\
\hline 2 & Arunachal Pradesh & 2 & 0.79 \\
\hline 3 & Chhattisgarh & 1 & 0.39 \\
\hline 4 & Gujarat & 36 & 14.12 \\
\hline 5 & Jharkhand & 1 & 0.39 \\
\hline 6 & Karnataka & 8 & 3.14 \\
\hline 7 & Kerala & 4 & 1.57 \\
\hline 8 & Madhya Pradesh & 10 & 3.92 \\
\hline 9 & Maharashtra & 11 & 4.3 \\
\hline 10 & New Delhi & 6 & 2.35 \\
\hline 11 & Punjab & 2 & 0.78 \\
\hline 12 & Rajasthan & 8 & 3.14 \\
\hline 13 & Tamil Nadu & 149 & 58.43 \\
\hline 14 & Telangana & 5 & 1.96 \\
\hline 15 & Uttar Pradesh & 4 & 1.57 \\
\hline 16 & Uttarakhand & 2 & 0.79 \\
\hline \multirow[t]{2}{*}{17} & West Bengal & 2 & 0.79 \\
\hline & & 255 & 100 \\
\hline
\end{tabular}

(Source: Different websites and analysis of data by the researcher)

\section{Assembling centers and their trading potentials of moringa produce}

Tamil Nadu has 4 important trading centers for Moringa produce. They are Udangudi of Thoothukkudi District; Aundipatti of Theni District; Aravakkurichi of Karur District and Oddanchatram of Dindigul District. In these markets, the Moringa pods are traded in large quantities where more number of traders could visit to meet their raw material requirement either for value addition or for direct sale to the consumer or to export the produce to other Metropolitan states like Mumbai or New Delhi. The average productivity of Moringa vegetable was arrived at 21 tonnes per ha. According to Ritambhara Singh et al., ${ }^{6}$ the average yield in Vadodara District was arrived at 19.50 tonnes per ha. This is almost equal to the yield obtained in respect of Tamil Nadu. Table 5 revealed that the state of Tamil Nadu alone could produce 2.81lakh tonnes of fresh Moringa vegetable pod for the need of consumers and industrial consumers for value addition. From the above 4 principal markets, the Moringa produce have been exported to different states. Among the 4 trading centers, Aundipatti market alone could handle highest share of Moringa produce followed by Oddanchatram market of Dindigul District which are respectively accounted for 30 per cent and 19.74 per cent to the total tradable quantity. Though the area under Moringa is available for different districts of Tamil Nadu, the Production and Productivity details of Moringa is not much documented and hence the Directorate of Economics and Statistics should take special efforts in collection of these data in conversation with the scientific institutions like Tamil Nadu Agricultural University regional research centers / Colleges available in these districts. Besides considering the potentials of Moringa in Tamil Nadu and its multiple value addition possibilities, the Government of India can think of establishing a National Research Centre on Moringa or Moringa Board may be established to activate the value addition and export further as it is increasingly popular on the European Market for food supplements. ${ }^{7}$ In the study, it has been aimed to collect data from different traders available in these two districts considered for the research. On analyzing, there could be few traders who are able to visit the potential markets stated above from different places. Among the visiting traders, the classification has been made based on their area of operation and hence these details are analyzed and the results are presented in Table 6 .

Table 6 revealed that the study area has only 30 per cent of the traders belonged to Commission agents and 40 per cent of the respondent traders belonged to wholesalers. Wholesaler cum exporters is 20 per cent in Thoothukkudi District and 30 per cent in Tiruppur District. The study area is in possession of mixed type of traders whom are performing different role to avoid competitiveness among them. The president, vegetable traders' association available in Tirunelveli decides the price to be fixed for different produce including Moringa. Whereas, in Tiruppur District, the President, Vegetable Merchants association available at Oddanchatram is deciding the price to be fixed for the agricultural produce Only one trader who has the multiple role of producer cum manufacturer cum exporter based at Madurai is visiting Thoothukkudi farmers for getting Moringa produce grown organically and his role has been taken as a Case Study and his activities are discussed in detail following a case approach.

\section{Marketing channels in the distribution process of moringa produce}

Marketing channel is the path way by which the commodity is 
transferred from the farmer producer to the ultimate consumers in which many of the intermediaries will have their own stake in the process of distribution of any commodity and they do either grading or processing or value addition of any kind. Identifying the marketing channel involves the flow of the produce, the cost involvement in transferring the produce, the margin earned by the intermediaries for their exclusive job in the distribution process. In this respect, the details of path ways have been traced for different products from the farmers and the traders while availing the interview during the survey. Table 4 Firms involved in manufacturing / trading of moringa products in Tamil Nadu

\begin{tabular}{|c|c|c|c|}
\hline SI. No. & $\begin{array}{l}\text { Name of the Districts } \\
\text { in Tamil Nadu }\end{array}$ & $\begin{array}{l}\text { Number of } \\
\text { Firms Involved }\end{array}$ & $\begin{array}{l}\text { Percentage to } \\
\text { Total }\end{array}$ \\
\hline 1 & Chennai & 23 & 15.44 \\
\hline 2 & Coimbatore & 36 & 24.16 \\
\hline 3 & Cuddalore & 1 & 0.67 \\
\hline 4 & Dharmapuri & 3 & 2.01 \\
\hline 5 & Dindigul & 11 & 7.38 \\
\hline 6 & Erode & 10 & 6.71 \\
\hline 7 & Kancheepuram & 1 & 0.67 \\
\hline 8 & Karur & 3 & 2.01 \\
\hline 9 & Krishnagiri & 2 & 1.34 \\
\hline 10 & Madurai & 15 & 10.07 \\
\hline 11 & Namakkal & 1 & 0.67 \\
\hline 12 & Pudukottai & 2 & 1.34 \\
\hline 13 & Ramanathapuram & 1 & 0.67 \\
\hline 14 & Salem & 7 & 4.7 \\
\hline 15 & Sivagangai & 1 & 0.67 \\
\hline 16 & Thanjavur & 1 & 0.67 \\
\hline 17 & Theni & 3 & 2.01 \\
\hline 18 & Thiruvarur & 2 & 1.34 \\
\hline 19 & Thirunelveli & 1 & 0.67 \\
\hline 20 & Tiruppur & 10 & 6.71 \\
\hline 21 & Tirichirappalli & 4 & 2.68 \\
\hline 22 & Thoothukkudi & 5 & 3.36 \\
\hline 23 & Vellore & 3 & 2.01 \\
\hline \multirow[t]{2}{*}{24} & Virudhunagar & 3 & 2.01 \\
\hline & Total & 149 & 100 \\
\hline
\end{tabular}

Source: Different websites and analysis of secondary data by the researcher)

Marketing of Moringa products are categorized into three important divisions. They are

1. Fresh Moringa Pod as Vegetables (Drumstick)

2. Moringa Seeds and

3. Value Added Products of Moringa

Before attempting to estimate the price spread prevalent in the trade of Moringa Products, the route through which the produce reaches the ultimate consumers from the producer or the manufacturer has to be critically analyzed and the pathways are traced and the details have to be documented. Accordingly, the details of distribution of Moringa products and their pathways have been identified and the details are presented in Table 7. In respect of Fresh Moringa (Drumstick), there were three channels through which the fresh Moringa pods were distributed to the ultimate consumers. Among the three channels, the researcher could estimate the price spread only in respect of Marketing Channel - III which could alone be traceable and hence the results are presented in Table 8 . In respect of value added products of Moringa, there were three channels involved in distribution of the produce to the ultimate consumers. Among the three channels, two are domestically operating pathways and the one is devoted for export of Moringa produce. The channel by which export takes place involves producer; Manufacturer cum Exporter; Wholesaler cum Import Permit Holder; distributors abroad and then it reaches the ultimate consumers of the respective country. This Channel is being operated for Malaysia; Germany and Canada. The other produce marketed is Moringa Seeds. It has two operative marketing channels exclusively for marketing the seeds abroad. The seeds are distributed to different countries including Ceylon. In respect of Moringa pods marketing, similar channels were identified by Rajendran \& Prahadeeswaran. ${ }^{8}$

\section{Price spread in marketing of moringa produce}

Price Spread (PS) is the difference between the producer's price and the consumer's price for a unit quantity at a given time. The price spread is otherwise called as Marketing Margin also. It has two components. They are marketing cost and the net margin for performing certain value-added functions by the specific intermediary in the channel. The price spread was estimated for the Moringa vegetables distributed through channel I - III were taken into account and the results are delineated in Table 8, Table 9 \& Table 10. Table 8 revealed that the Moringa vegetables were sold by the farmers in the Farmers' Market through Channel - I. For that the farmers were forced to incur some costs. The costs actually incurred by them were arranging the pods or grading the pods based on their length and are packed in different packs preferably in Gunny bags. For that he extends some family labor or the labor whom can visit the farm on regular basis will be paid with some grading charges. The packing and grading charges were arrived at 40 paisa per $\mathrm{kg}$ of the produce. Though the transportation is free to them, some cost on regular basis they have to provide to the crew members of the transport and hence the transportation charges. Put together, the marketing cost in Channel - I is arrived at Rupee one for one $\mathrm{kg}$ and then the margin is fixed in the farmers' market which is around 20 per cent and the consumer price fixed was Rs. 20 in Thoothukkudi District. Whereas, the consumer price fixed was Rs 23perkg in Tiruppur. The Marketing Margin received by the producer cum trader is around Rs one per kg in Thoothukkudi District and Rs 1.80 per kg in Tiruppur District. On an average, through this marketing channel, the producer is able to secure around 88 to 90 per cent share from the consumer's price. It is appreciable because the farm producer was directly sold in the Farmers' Market. Considering too much distance between Sathankulam to Thoothukkudi Farmers' Market, recent days the farmers are reluctant to visit the Farmers' Market and they distribute the produce to the Commission Agent cum Wholesaler and the Channel is presented in Table 9.

Table 9 revealed a different channel where the farmers unable to perform a visit to Farmers' market were selling their produce to the Commission Agent cum Wholesaler who is able to visit their farm regularly and the average price received by the farmer does not differ 
from channel to channel. But the percentage share alone changes due to different intermediaries and their expenses towards distribution of vegetables. Here the Thoothukkudi farmers were able to receive 64 per cent of the consumers' price as their share. Whereas in, Tiruppur District, the farmers were able to receive 65 per cent of the consumers' price as their share. In general, the percentage share received by the farmers was appreciable in Channel - I and Channel - II. In Channel - II the retailer is able to gain considerable margin. That margin is arrived at around 26 per cent of the consumers' price. The percentage share to retailer in Tiruppur District is little less than their counterpart in Thoothukkudi District. But, the absolute share is little higher to the Retailer in Tiruppur District. Even though the facilities are available, the farmers were reluctant to visit farmers' market and hence a new farmers' market nearby Sathankulam area is needed and hence the Department of Horticulture and Plantation crops officials can take special effort to erect a new farmers' market in Sathankulam areas of
Thoothukkudi District. Table 10 revealed that the Moringa vegetables produced in Tamil Nadu are distributed through four important assembling centers discussed elsewhere. The fresh Moringa vegetables were exported from these assembling centers with the intervention of different traders to the different states like Mumbai, New Delhi. In the price spread estimation, only three channels could be traceable from the wordings of the traders and the same are presented in the Table 7. Here the produce flows from Farmer-Producer to the Commission agent. The commission agent has received the produce at the rate of Rs. 13 per $\mathrm{kg}$ and he do some marketing functions like grading, packing and forwarding and placed the produce to the wholesaler at the rate of Rs 15 per kg after having a commission of Rs. 1.00 per $\mathrm{kg}$. But this is quite different in Tiruppur District. Here the purchase price from the producer itself is little bit high when compared to the procurement price prevailed in Thoothukkudi District due to the quality difference in the Moringa Pods.

Table 5 Assembling centers and their trading potentials of moringa in Tamil Nadu

\begin{tabular}{llllll}
\hline SI. No. & Assembling Centers & $\begin{array}{l}\text { Name of the } \\
\text { District }\end{array}$ & $\begin{array}{l}\text { Area under } \\
\text { Moringa in Ha }\end{array}$ & $\begin{array}{l}\text { Average Yield in } \\
\text { Tonnes / Ha }\end{array}$ & $\begin{array}{l}\text { Av. Quantity Produced and Traded } \\
\text { in Tonnes per Annum }\end{array}$ \\
\hline 1 & Udangudi & Thoothukkudi & 1465 & 20 & $29300(10.42)$ \\
2 & Aundipatti & Theni District & 3424 & 25 & $85600(30.43)$ \\
3 & Aravakkurichi & Karur District & 2070 & 22 & $45540(16.19)$ \\
4 & Oddanchatram & Dindigul District & 2645 & 21 & $55545(19.74)$ \\
5 & Other Centers & Other Districts & 3438 & 19 & $65322(23.22)$ \\
& $\begin{array}{l}\text { Tamil Nadu as a } \\
\text { Whole }\end{array}$ & & 13042 & 21 & $281307(100.00)$
\end{tabular}

(Source: Primary survey; directorate of economics and statistics, government of Tamil Nadu)

Table 6 Details of type of traders available for procuring moringa produce

\begin{tabular}{llll}
\hline SI. No. & Type of Traders & $\begin{array}{l}\text { Number of Sample Traders in } \\
\text { Thoothukkudi District }\end{array}$ & $\begin{array}{l}\text { Number of Sample Traders in } \\
\text { Tiruppur District }\end{array}$ \\
\hline 1 & Commission Agents & $03(30.00)$ & $03(30.00)$ \\
2 & Wholesalers & $04(40.00)$ & $04(40.00)$ \\
3 & Wholesalers cum Exporters & $02(20.00)$ & $03(30.00)$ \\
4 & Producer cum Manufacturer cum Exporter & $01(10.00)$ & 0 \\
\end{tabular}

(Source: Primary Survey)

Table 7 Marketing channels prevalent in the distribution of moringa produce

\begin{tabular}{ll}
\hline Channel Number & Details of intermediaries involved in the distribution process \\
\hline I & Fresh Moringa Pod- Drumstick \\
II & Farmer Producer à Consumers / Industrial Consumers \\
III & Farmer Producer à Commission Agent cum Wholesaler àRetailers à Consumers \\
& Producer à Commission Agent à Wholesalers in Tamil NaduàWholesalers at Mumbai / Delhi àRetailers à Consumers \\
I & Value Added Products of Moringa \\
II & Producer à Industrial Consumers \\
III & Producer à Manufacturer à Distributors (Wholesalers) à Dealers (Retailers) à Consumers \\
& Producer à Manufacturer cum Exporter à Wholesaler cum Import Permit HolderàDistributors Abroadà Consumers Abroad \\
I & Moringa Seeds \\
II & Producer cum Exporter à Distributors Abroad à Consumers \\
& Producer à Seed Processor cum Exporter à Plant Quarantine Agency à Distributor of Seeds Abroad à Consumers
\end{tabular}


Table 8 Price spread estimation for marketing channel - I

Farmer Producer $\rightarrow$ Consumers / Industrial Consumers

\section{SI. No. Particulars of Cost}

\section{Amount in Rs per Kg of \\ Moringa in}

\section{Thoothukkudi District Tiruppur District Average}

\section{$1 \quad$ Producer}

1 Producers' Price

$18.00(90.00)$

$20.00(86.95)$

$19.00(88.37)$

$1.1 \quad$ Marketing Cost Incurred by Producer

1.1.1 Grading and Packing Charges 0

1.1.2 Transportation Charges from Village to

$\begin{array}{lll}0.4 & 0.5 & 0.45\end{array}$

Farmers' Market
1.1.3 Assembling the Produce and Distribution

$\begin{array}{lll}0.2 & 0.2 & 0.2\end{array}$

1.1.3 Charges

0.2

1.1.4 Miscellaneous Charges

0.2

Total Marketing Cost

$01.00(05.00)$

0.2

0.2

Marketing Margin to the Producer

$01.00(05.00)$

0.3

0.25

Consumers' Price

$20.00(100.00)$

$01.20(05.22)$

$01.10(05.12)$

$01.80(07.83)$

$01.40(06.51)$

2

$23.00(100.00)$

Source: Primary survey figures parenthesis indicate in percentage to consumer's price

Table 9 Price spread estimation for marketing channel - II

Farmer Producer $\rightarrow$ Commission Agent cum Wholesaler $\rightarrow$ Retailers $\rightarrow$ Consumers

\begin{tabular}{|c|c|c|c|c|}
\hline \multirow{2}{*}{ SI. No. } & \multirow{2}{*}{ Particulars of Cost } & \multicolumn{2}{|l|}{$\begin{array}{l}\text { Amount in Rs per Kg of } \\
\text { Moringa in }\end{array}$} & \multirow{2}{*}{ Average } \\
\hline & & Thoothukkudi District & Tiruppur District & \\
\hline 1 & Producer & & & \\
\hline 1 & Producers' Price & $16.00(64.00)$ & $18.00(66.67)$ & $17.00(65.39)$ \\
\hline 1.1 & $\begin{array}{l}\text { Marketing Cost Incurred by Commission Agent cum } \\
\text { Wholesaler }\end{array}$ & & & \\
\hline 1.1 .1 & Grading and Packing Charges & 0.4 & 0.5 & 0.45 \\
\hline 1.1 .2 & $\begin{array}{l}\text { Transportation Charges from Village to Wholesale } \\
\text { Market }\end{array}$ & 0.4 & 0.3 & 0.35 \\
\hline 1.1 .3 & Assembling the Produce and Distribution Charges & 0.3 & 0.3 & 0.3 \\
\hline \multirow[t]{3}{*}{1.1 .4} & Miscellaneous Charges & 0.4 & 0.5 & 0.45 \\
\hline & Total Marketing Cost & $01.50(06.00)$ & 1.6 & $01.55(05.96)$ \\
\hline & $\begin{array}{l}\text { Marketing Margin to the Commission Agent cum } \\
\text { Wholesaler }\end{array}$ & $02.50(10.00)$ & $02.40(08.89)$ & $02.45(09.42)$ \\
\hline 2 & Selling Price to Retailer & 20 & 22 & 21 \\
\hline 2.1 & Marketing Cost to Retailer & & & \\
\hline 2.1 .1 & Packing and Transportation Charges & 0.6 & 0.5 & 0.55 \\
\hline \multirow[t]{2}{*}{2.1 .2} & Miscellaneous Cost & 0.4 & 0.3 & 0.35 \\
\hline & Total Marketing Cost & $1.00(04.00)$ & 0.8 & $00.90(03.46)$ \\
\hline 2.3 & Marketing Margin to Trader & $04.00(16.00)$ & $04.20(15.56)$ & $04.10(15.77)$ \\
\hline 3 & Selling Price to Consumer & $25.00(100.00)$ & $27.00(100.00)$ & $26.00(100.00)$ \\
\hline
\end{tabular}

Source: Primary survey figures parenthesis indicate in percentage to consumer's price 
Table 10 Price spread in marketing of fresh moringa pods (drumstick)

Producer $\rightarrow$ Commission Agent $\rightarrow$ Wholesalers (Tamil Nadu) $\rightarrow$ Wholesalers at Mumbai / Delhi $\rightarrow$ Retailers $\rightarrow$ Consumers

\begin{tabular}{|c|c|c|c|c|}
\hline SI. No & Particulars of Cost & $\begin{array}{l}\text { Amount (Rs / Kg) in } \\
\text { Thoothukkudi District }\end{array}$ & $\begin{array}{l}\text { Amount (Rs / Kg) in } \\
\text { Tiruppur District }\end{array}$ & Average \\
\hline 1 & Producer & & & \\
\hline 1 & Producers' Price & $13.00(38.23)$ & $15.00(37.50)$ & $14.00(37.84)$ \\
\hline 1.1 & Marketing Cost Incurred by Commission Agent & & & \\
\hline 1.1 .1 & Processing and Grading Charges & 0.3 & 0.4 & 0.35 \\
\hline 1.1.2 & Assembling and Packing Charges & 0.3 & 0.4 & 0.35 \\
\hline 1.1 .3 & Cost of Labor in Loading and Forwarding Charges & 0.2 & 0.35 & 0.27 \\
\hline 1.1 .4 & Miscellaneous Charges to the Commission Agent & 0.2 & 0.35 & 0.28 \\
\hline 1.1 & Marketing Cost at Commission Agent Level & 1 & 1.5 & $01.25(03.38)$ \\
\hline 1.2 & Commission Charges & 1 & 1.5 & $01.25(03.38)$ \\
\hline 2 & Wholesaler & & & \\
\hline 2.1 & Procurement Price by the Wholesaler & 15 & 18 & 16.5 \\
\hline 2.2 & Marketing Cost & & & \\
\hline 2.2 .1 & $\begin{array}{l}\text { Transportation Charges to outside the Markets of Tamil } \\
\text { Nadu }\end{array}$ & 2.75 & 3 & 2.88 \\
\hline 2.2 .2 & Loading and Unloading Charges & 0.5 & 0.5 & 0.5 \\
\hline \multirow[t]{2}{*}{2.2 .3} & $\begin{array}{l}\text { Miscellaneous Charges including Check post and } \\
\text { Octroi }\end{array}$ & 2.25 & 2 & 2.13 \\
\hline & Marketing Cost at Wholesaler Level & 5.5 & 5.5 & $05.50(14.86)$ \\
\hline 2.3 & Marketing Margin to the Wholesaler & $03.50(10.29)$ & $03.50(08.75)$ & $03.50(09.46)$ \\
\hline 3 & Wholesaler (Mumbai / Delhi) & & & \\
\hline 3.1 & $\begin{array}{l}\text { Purchase Price Incurred by the Wholesaler (Mumbai } \\
\text { / Delhi) }\end{array}$ & 24 & 27 & 25.5 \\
\hline 3.2 & Marketing Cost & & & \\
\hline 3.2 .1 & Loading and Unloading Charges & 0.6 & 0.6 & 0.6 \\
\hline 3.2 .2 & Transportation Charges & 0.8 & 1 & 0.9 \\
\hline 3.2 .3 & Miscellaneous Cost including Rent & 0.3 & 0.4 & 0.35 \\
\hline 3.2 & Marketing Cost to the Wholesaler & 1.7 & 2 & $01.85(05.00)$ \\
\hline 3.3 & Marketing Margin to the Wholesaler (Mumbai/Delhi) & $03.30(10.31)$ & $03.00(08.57)$ & $03.15(08.51)$ \\
\hline 3.4 & Sale Price to the Retailer & 29 & 32 & 30.5 \\
\hline 4 & Retailer & & & \\
\hline 4.1 & Procurement Price by the Retailer & 29 & 32 & 30.5 \\
\hline 4.2 & Marketing Cost to the Retailer & & & \\
\hline 4.2 .1 & Transportation Charges & 0.6 & 1 & 0.8 \\
\hline 4.2 .2 & $\begin{array}{l}\text { Cost of Labor in Packing and Distribution of Moringa } \\
\text { and other Vegetables }\end{array}$ & 0.5 & 0.6 & 0.55 \\
\hline 4.2 .2 & Miscellaneous Charges Including Rent & 0.4 & 0.4 & 0.4 \\
\hline 4.2 & Marketing Cost to the Retailer & 1.5 & 2 & $01.75(04.73)$ \\
\hline 4.3 & Marketing Margin to the Retailer & $03.50(10.29)$ & $04.00(10.00)$ & $03.75(10.14)$ \\
\hline 5 & Sale Price to the Consumer and the Consumer's Price & $34.00(100.00)$ & $40.00(100.00)$ & $37.00(100.00)$ \\
\hline
\end{tabular}

Source: Primary survey figures parenthesis indicate in percentage to consumer's price 
The wholesalers in Thoothukkudi District received the produce at the rate of Rs 15perkg and the wholesalers in Tiruppur District had received the same at Rs 18 per $\mathrm{kg}$ and does transportation, packing and forwarding after incurring a marketing cost of Rs 5.50perkg and he has added a margin of Rs 3.50perkg and sold it to the wholesalers at Mumbai at the rate of Rs 24 per kg. Whereas, the produce was sold to New Delhi wholesalers at the rate of Rs 27perkg and finally, the produce reaches the ultimate consumers at the rate of Rs 34perkg at Mumbai and Rs 40perkg at New Delhi. The percentage of margin gained by the intermediaries in respect of Thoothukkudi Channel is little bit high when compared to the Tiruppur Channel. Thoothukkudi and Tiruppur farmers were able to gain almost equal share of 38 per cent from consumer's price. Though the produce moves in the same channel, the marketing cost differs between the intermediaries. However, higher advantage of producer's price is visible to the Tiruppur farmers as they have their own ways of doing the transaction across the states. The average price received was found to be different as Tiruppur farmers had price advantage in some occasions resulted in higher price per unit of the produce. According to Ted Radovich ${ }^{9}$ Moringa products, particularly the Moringa Pods may be retailed at higher prices if marketed in certain venues as exotic, nutrient rich vegetables. In this circumstance, the average price received by the producer, the average price paid by the consumer and the price spread for the study area as a whole is analyzed and the results are presented in Table 11. Table 11 revealed that the price spread is varying across the channel. The variation is from 11.63 per cent to 62.16 per cent per $\mathrm{kg}$ of Moringa vegetables. From the channel $-\mathrm{I}$ alone, the price spread is found to be Minimum and the Maximum is vested with the ChannelIII. From that one could infer that the Marketing Channel - I alone is favorable to the producer and the consumer as these two are benefitted much from the channel. Whereas, the other two channels are not contributing much to the producer and the consumer. But these two are beneficiary channels to the intermediaries. In this circumstance, one should analyze the efficient channel which is discussed under the title of 'Marketing Efficiency'.

\section{Marketing efficiency}

There were many marketing channels available for each and every produce produced or manufactured from Moringa. Among these, only the marketing efficiency was arrived at for Moringa vegetables marketing. It involved only three marketing channels. All these channels were analyzed and the results are presented in Table 12. Table 12 revealed that the marketing channel - I was found to be more efficient when compared to all other channels in the marketing of Moringa vegetables (Pod). It is mainly due to direct marketing performed by the producer by accessing Farmers' Market and hence he could command higher price per unit of the produce. Similar direct marketing approach is practiced among the Garlic Producers who turned into producer cum traders also and earn higher share from the consumers' rupee. ${ }^{3}$ Whereas, the other channels were routed through either one or more intermediaries like commission agent or wholesalers, the channel - III is capable of meeting the requirements of intermediaries.

Table I I Price spread in different channels of moringa marketing

\begin{tabular}{lllll}
\hline SI. No. & $\begin{array}{l}\text { Marketing } \\
\text { Channel }\end{array}$ & $\begin{array}{l}\text { Price Received by the Producer in Rs } \\
\text { per Kg }\end{array}$ & $\begin{array}{l}\text { Price Paid by the Consumer in Rs } \\
\text { per Kg }\end{array}$ & $\begin{array}{l}\text { Price Spread in Rs } \\
\text { per Kg }\end{array}$ \\
\hline 1 & Channel - I & $19.00(88.37)$ & $21.50(100.00)$ & $02.50(11.63)$ \\
2 & Channel - II & $17.00(65.38)$ & $26.00(100.00)$ & $09.00(34.62)$ \\
3 & Channel - III & $14.00(37.84)$ & $37.00(100.00)$ & $23.00(62.16)$
\end{tabular}

Table I 2 Marketing efficiency in marketing of moringa pods

\begin{tabular}{|c|c|c|c|c|}
\hline SI. No. & $\begin{array}{l}\text { Marketing } \\
\text { Channel }\end{array}$ & $\begin{array}{l}\text { Net Price Received by the Farmer / } \\
\text { Kg in Rs }\end{array}$ & $\begin{array}{l}\text { Marketing Cost + Marketing Margin } \\
\text { in } \mathbf{R s} / \mathrm{Kg}\end{array}$ & $\begin{array}{l}\text { Marketing } \\
\text { Efficiency }\end{array}$ \\
\hline I & Acharya Approach & & & \\
\hline 1 & Channel - I & 19 & 2.5 & 7.6 \\
\hline 2 & Channel - II & 17 & 9 & 1.89 \\
\hline 3 & Channel - III & 14 & 22 & 0.64 \\
\hline II & Shepherd's Approach & & & \\
\hline 1 & Channel - I & 19 & 1.05 & 17.09 \\
\hline 2 & Channel - II & 17 & 2.45 & 5.94 \\
\hline 3 & Channel - III & 14 & 10.35 & 1.35 \\
\hline
\end{tabular}

\section{Summary and conclusion}

Value addition of Moringa Produce and its Marketing has become a Principal activity among the traders. Though India had 255 Numbers of Traders dealing with Moringa Produce, Tamil Nadu alone had 58 per cent of traders of Moringa produce. It was mainly due to higher area under Moringa and good Market demand. The Value-added
Produce was distributed through eight important channels. Among which Moringa pod alone was distributed through three different channels. Among the three channels, the Channel - I was found to be efficient with respect to addition of higher share to the producers. The supply and value chain in respect of Moringa are not well defined and regulated and are distributed to the needy through some middlemen. Being the demand oriented and high revenue earner, the regulated 
supply and value chain becomes important and hence a "Moringa Board" can be thought off to establish on the lines of Tea Board or Coffee Board to impart efficiency in production and distribution of Moringa produce through appropriate intervention.

\section{Acknowledgements}

None.

\section{Conflict of interest}

Author declares that there is no conflict of interest.

\section{References}

1. Estrella MCP, Mantarin JBV, David GZ. A double blind, randomized controlled trial on the use of Malunggay (Moringa oleifera) for augmentation of the volume of breastmilk among non-nursing mothers of preterm infants. Philippines Journal of Pediatrics. 2000;49(1):3-6.

2. Siddhuraju P, Becker K. Antioxidant properties of various solvent extracts of total phenolic constituents from three different agro-climatic origins of drumstick tree (Moringa oleifera Lam.). J Agric Food Chem. 2003;51(8):2144-2155
3. Sekhar C, Prahadeeswaran M, Nagaraj R. Garlic trading - a potential agribusiness venture in India. $J$ Horticulture. 2015;1(3):1-11.

4. Acharya SS, Agarwal NL. Agricultural marketing in India. New Delhi: Oxford and IBH Publishing Company; 1994;302-312.

5. Sekhar C. Production and marketing of chilli. Scholars Press: Germany. $2014 ; 75-120$.

6. Ritambhara Singh, Prajapati MR, Jemish Savani. Economics of production of drumstick (Moringa olifera) in Vadodara District of Gujarat. Int J Adv Biol Res. 2017;7(2):322-328.

7. CBI-Ministry of Foreign Affairs. Exporting moringa to Europe. Centre for promotion of imports from developing countries, Ministry of Foreign Affairs: The Netherlands: 2018.

8. Rajendran T, Prahadeeswaran M. Marketing strategies for promotion of annual moringa in Tamil Nadu - An Economic Analysis. J Management Res. 2014;2(1):289-295.

9. Radovich $\mathrm{T}$. farm forestry production and marketing profile for moringa In: Specialty crops for Pacific Island Agroforestry. Elevitch CR. editor. Hawai: Permanent Agriculture Resources; 2009;10. 